\title{
新規の脂肪酸組成を持つダイズ油の突然変異による改良 Development of Novel Fatty Acid Composition in Soybean Oil by Induced Mutation
}
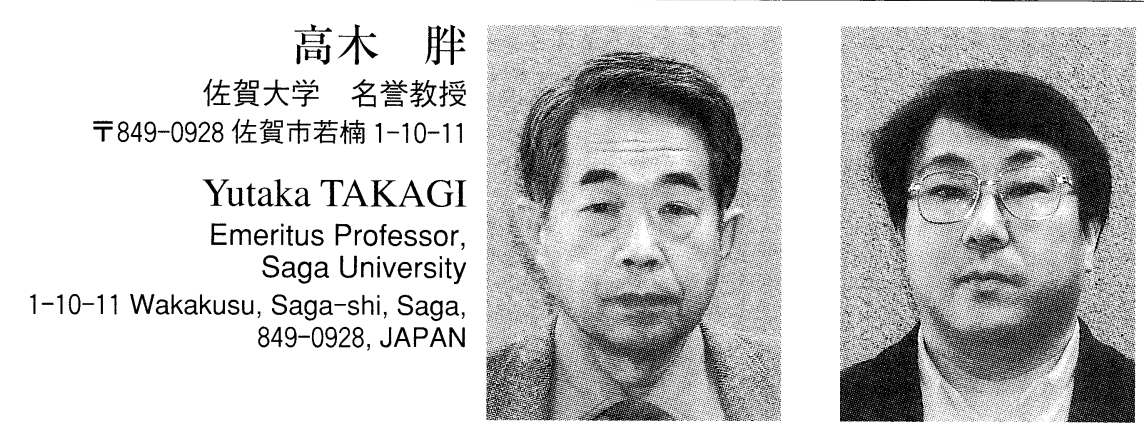

穴井豊昭

佐賀大学農学部 植物育種学分野

于840-8502 佐賀市本庄町 1

Toyoaki ANAI

Laboratory of Plant Breeding,

Faculty of Agriculture,

Saga University,

1 Honjo-machi, Saga-shi, Saga,

840-8502, JAPAN

論文要旨：ダイズ油は, マーガリン, ショートニング, サラダ油, 揚げ物用に使用されており, 消費量の 多い食用油脂である。ダイズ油中の多価不飽和脂肪酸を隇少させる改良（オレイン酸含量を増加させリノー ル酸とリノレン酸含量を減少させる）は，人の健康にまたダイズ油の酸化安定性の向上には極めて有効であ る。しかしながら，ダイズでは，オレイン酸とリノレン酸の含量を変える遺伝資源が限られていることから， 突然変異体の利用が有効であると考えられ，化学物質や X 線照射等による遺伝変異の拡大が図られてきた。 その結果, これまでに, 高·低のパルミチン酸含量, 高ステアリン酸含量, 高オレイン酸含量, 低リノレン 酸含量の諸種の突然変異が得られるとともに，これらの脂肪酸組成を支配する主動遺伝子の支配が明らかに されてきた。現在では, これらの突然変異遺伝子を組合せることで, これまでにない新しい脂肪酸組成を持 つダイズの育種が可能となっている。本報告では, ダイズの脂肪酸組成を大きく変える新しい遺伝子の発見 を中心として，50\%を越える高オレイン酸含量で $3 \%$ 以下の低リノレン酸含量となるダイズの作出に至る最 近の育種の進歩について述べる。

\begin{abstract}
Soybean is the most widely used source of edible oil for human consumption. It is consumed predominantly in the form of margarine, shortening, and salad and frying oils. Altered unsaturated fatty acid content (elevated oleic acid and reduced linolenic acid) increases oxidative stability which have high usefulness in food for health benefits as well as in industry. Natural genetic variability for oleic and linolenic acid content in commercial soybean is limited. The most effective method for modifying fatty acid composition in soybean oil is mutagenesis. With the help of X-rays or chemical mutagens, it has become possible to develop different mutants with different fatty acid composition. Mutants with significantly reduced and elevated palmitic acid, elevated stearic acid, elevated oleic acid, and reduced linolenic acid content were isolated and found to be controlled by major genes. In this paper, gene discovery with altered fatty acid composition and development of novel soybean lines by combining multiple mutant alleles, and also recent progress of oleic acid with elevated content (50.0\%) and linolenic acid with reduced content $(3 \%)$ in soybean oil, are discussed.
\end{abstract}

Key words: Soybean Oil, Improvement of Fatty Acid, High Oleic Acid, Low Linolenic Acid, Induced Mutation

\section{1 はじめに}

ダイズは，ナタネに次いで油脂生産量が多く, 油糧作

連絡者: 高木 胖

E-mail : sukeyuki@po.bunbun.ne.jp
物として世界的に重要な位置を占めている。植物油脂の 主要な用途は, 調理用, 生食用, ショートニング, マー ガリン用などであるが, 脂肪酸組成の違いは油の物理的 特性, 酸化安定性, 栄養価等に大きな影響を与えてい る。Table 1 は, 諸種の植物油脂の脂肪酸組成と市場価 
Table 1 Fatty Acid Composition (\% of total oil) of Different Vegetable Oils, and Their Market Prices.

\begin{tabular}{|c|c|c|c|c|c|c|c|c|}
\hline \multirow[b]{2}{*}{ Seed Oil } & \multicolumn{8}{|c|}{ Fatty acid } \\
\hline & $\begin{array}{c}\text { Palmitic } \\
(16: 0)\end{array}$ & $\begin{array}{l}\text { Stearic } \\
(18: 0)\end{array}$ & $\begin{array}{c}\text { Oleic } \\
(18: 1)\end{array}$ & $\begin{array}{c}\text { Linoleic } \\
(18: 2)\end{array}$ & $\begin{array}{c}\text { Linolenic } \\
(18: 3)\end{array}$ & $\begin{array}{c}\text { Eicosenoic } \\
(20: 1)\end{array}$ & $\begin{array}{l}\text { Erucic } \\
(22: 1)\end{array}$ & $\begin{array}{c}\text { Price } \\
(\text { Yen/18 } \ell)\end{array}$ \\
\hline Rape (classic) & 4.0 & 1.5 & 17.0 & 13.0 & 9.0 & 14.5 & 41.0 & 5,000 \\
\hline Rape (zero erucic) & 9.2 & 1.6 & 59.1 & 19.4 & 10.2 & 0.2 & 0.3 & 3,100 \\
\hline Soybean & 11.5 & 3.9 & 24.6 & 52.0 & 8.0 & - & - & 3,000 \\
\hline Corn & 12.1 & 2.3 & 28.7 & 56.2 & 0.7 & - & - & 3,500 \\
\hline Sunflower (classic) & 6.4 & 4.8 & 19.6 & 68.7 & $<0.5$ & - & - & 4,000 \\
\hline Sunflower (mid oleic) & 4.5 & 4.4 & 54.3 & 36.3 & $<0.5$ & - & - & 5,000 \\
\hline Sunflower (high oleic) & 3.6 & 4.2 & 81.4 & 10.3 & $<0.5$ & - & - & 7,000 \\
\hline Safflower (classic) & 7.2 & 2.1 & 9.7 & 81.0 & 0.0 & - & - & 7,000 \\
\hline Safflower (high oleic) & 5.4 & 2.3 & 80.0 & 12.3 & 0.0 & - & - & 7,000 \\
\hline Olive & 14.6 & 3.1 & 76.2 & 5.5 & 0.6 & - & - & 11,000 \\
\hline Palm & 43.0 & 4.1 & 44.2 & 8.7 & 0.0 & - & - & 2,500 \\
\hline
\end{tabular}

格を示したものである。ダイズの脂肪酸組成は，低い才 レイン酸含量（高リノール酸含量）と高いリノレン酸含 量を特徵としており，他の植物油脂とくらべると市場価 格が低くなっている。

この理由の一つとして，ダイズ油中に大量に含まれる 多価不飽和脂肪酸（リノール酸とリノレン酸）は，油の 自動酸化による品質の劣化と過酸化物発生の原因となる ことがあげられる。これに対して，一価の不飽和脂肪酸 であるオレイン酸は血液中の過剩なコレステロールを低 下させる効果があることから ${ }^{1)}$, 血管性の疾患による心 臟病（cardiovascular disease）の予防といった観点から も, 高オレイン酸のヒマワリ油, ベニバナ油, オリーブ 油等に注目が集まっている。また，不飽和脂肪酸の自動 酸化による過酸化脂質の増加は家畜の慨となるダイズ ミールでも問題となっており，ダイズ油脂の酸化安定 （oxidative stability）を増すために，オレイン酸含量を 増加させ, 多価不飽和脂肪酸を減少させる脂肪酸組成の 改良が極めて重要な課題となっている ${ }^{2,3)}$ 。具体的には, ダイズ脂肪酸組成のうち 7 ～8\%を占めるリノレン酸は 空気中の酸素と反応して不快な臭い（off-flavor）の原因 物質となることから ${ }^{4)}$ ，この含量を $2 \sim 3 \%$ まで低下さ せる必要があるとされてきた ${ }^{3,5)}$ 。さらに, 最近では, 水 素添加処理の際に生成するトランス型脂肪酸を減らす目 的から，ダイズのリノレン酸を $1 \%$ 以下にする改良が望 まれている6。

われわれは, 1986 年に研究を開始し, ダイズ品種 BayにX 線を照射した変異集団から, 諸種の脂肪酸含 量が変化した突然変異体を単離し, ダイズの脂肪酸組成 を支配する遺伝子についての解析を続けてきた。本稿で は，この研究から得られた新規の脂肪酸組成を持つダイ ズについて，また，W.R. Fehr と E.G. Hammond ら (Iowa State University) によって行われてきたダイズ 脂肪酸組成を改良する研究成果を紹介することにする。

\section{2 油糧作物における脂肪酸組成の変異と遺伝子による 支配}

\section{$2 \cdot 1$ 脂肪酸生合成と遺伝子}

油糧作物は, その種類によって特徴ある脂肪酸組成を 持つ油脂を生産する（Table 1)。従来型のナタネ（classic）では，エイコセン酸とエルカ酸含量がそれぞれ $14.5 \%$ と $41.0 \%$ と高く, 他の油糧作物のダイズ, トウモ ロコシ，ヒマワリ (classic), ベニバナ (classic) では リノール酸含量が $52.0 \% ， 56.2 \% ， 68.7 \% ， 81.0 \%$ と高 く, オレイン酸含量は $24.6 \% ， 28.7 \% ， 19.6 \% ， 9.7 \%$ と 低い。リノレン酸含量はダイズで $8.0 \%$ と高く, 他の, トウモロコシ，ヒマワリ (classic), ベニバナ（classic） では殆ど認められない。オリーブでは $76.2 \%$ 高オレイ ン酸含量で $5.5 \%$ の低いリノール酸含量である。パーム では，パルミチン酸含量とオレイン酸含量がそれぞれ $43.0 \%$ と $4.2 \%$ と高いのが特徴である。このように, 脂 肪酸組成は油糧作物の種によって, また, ナタネ（zero erucic), ヒマワリ (mid oleic, high oleic), ベニバナ （high oleic）等では改良種と従来種の間で大きく異な り，極めて多様性が高い。

これら油糧作物における脂肪酸の生合成経路を整理す ると, Fig. 1 に示すように，一つはすべての植物種に共

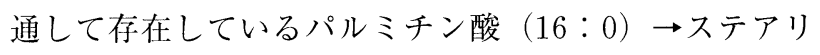
ン酸（18：0）の炭素鎖伸長反応，およびステアリン酸

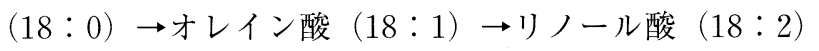
カリノレン酸 $(18: 3)$ への不飽和化反応の経路と, ナ タネ（classic）のみに見られるオレイン酸 $(18: 1) \rightarrow$

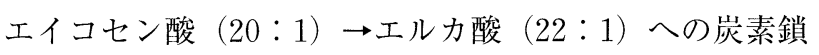
伸長反応がある。油糧作物に特徵的な脂肪酸組成は, 脂 肪酸の炭素鎖伸長反応と不飽和化反応の各ステップに関 与する酵素の活性（正確には個々の酵素の活性とこれを 


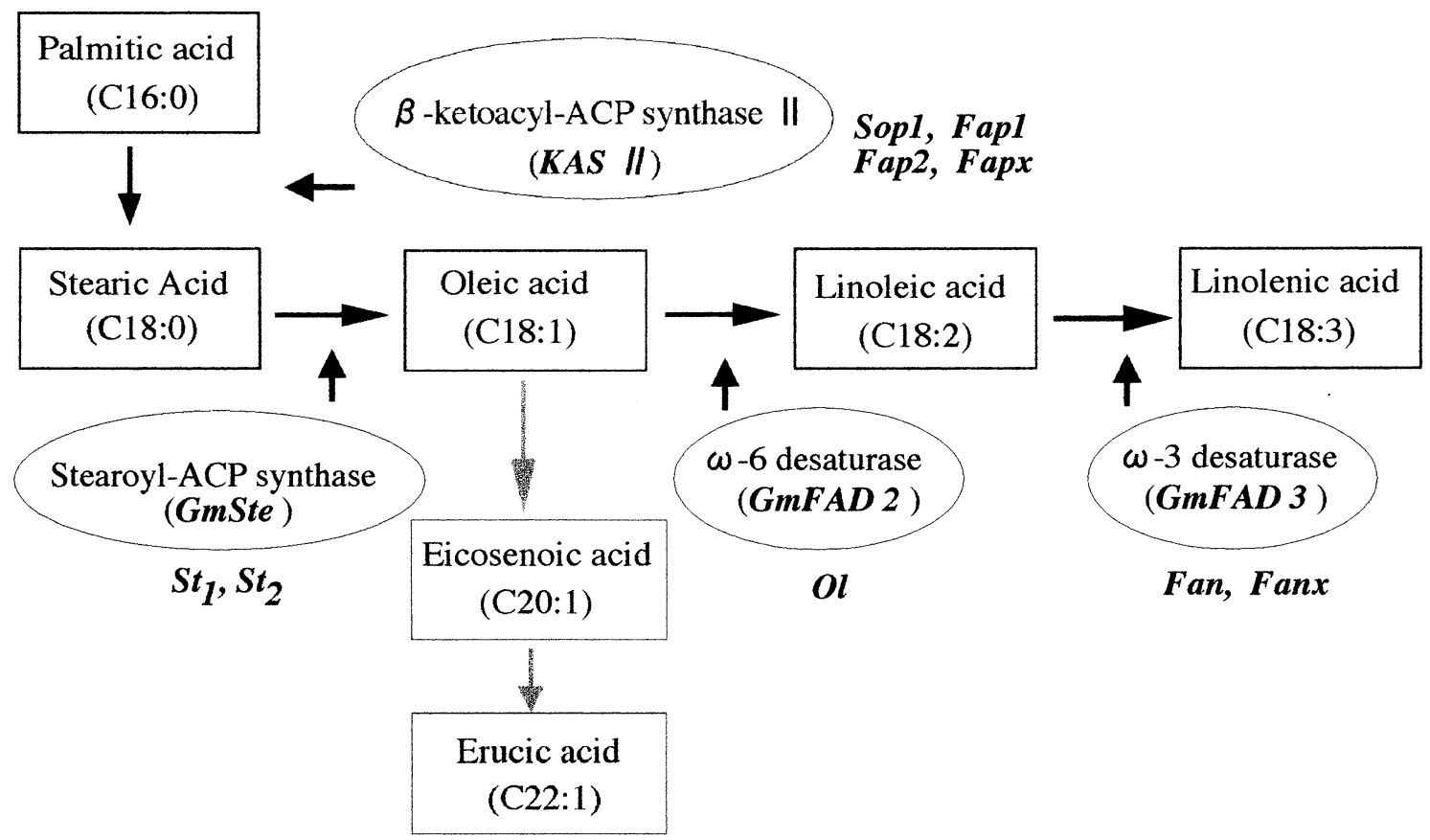

Fig. 1 Genes Responsible for Different Fatty Acid Biosynthesis.

コードする遺伝子数の双方）に差異があるためであり， 脂肪酸生合成経路の多様な遺伝子による支配を示唆する ものであった。

油糧作物の品種改良は，まずは自然集団の中から目的 とする遺伝子を発見してその遺伝子を育種の場に取り达 むことから始まった。例えば，従来型の高エルカ酸ナ夕 ネ（classic）を改良し，ゼロエルカ酸ナタネ（zero erucic）を作出した例では，世界各地から収集したナ夕ネ遺 伝資源の広範なスクリーニングを行い, Polish 品種から エルカ酸含量を変えてゼロにする遺伝子を発見してい る。従来型ナタネ（classic）は累積的に働く2 対の同義 遺伝子 $E_{1} E_{1} E_{2} E_{2}$ によりエイコセン酸 $(20: 1)$ とエルカ 酸（22:1）の合成が支配されているが，改良種（zero erucic）では $e_{1} e_{1} e_{2} e_{2}$ となり，これらの脂肪酸の含量はゼ 口となる ${ }^{7)}$ 。これは, ナ夕ネの脂肪酸の生合成経路にお

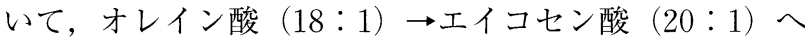
の炭素鎖伸長反応を支配する 2 個の遺伝子 $E_{1} E_{2}$ を $e_{1} e_{2}$ に変えることにより，この経路が遮断されエルカ酸を蓄 積しなくなったと考えられる。また，脂肪酸含量を大き く変える他の例としては, Table 1 に示した高オレイン 酸含量となるべニバナ（high oleic）がある。この場合 にも, Pakistanの在来種から発見された高オレイン酸含 量となる ol 遺伝子を利用しており，従来型のベニバナ （classic）ではオレイン酸含量が約 10\%であったものを 約 $80 \%$ にまで増加させており，これに伴って，リノー ル酸含量は約 $10 \%$ に減少している。これは，ol遺伝子

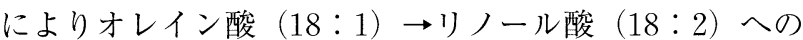

不飽和化反応が阻止されたためであると考えられた

\section{$2 \cdot 2$ ダイズの脂肪酸組成についての品種間変異}

ダイズの脂肪酸組成の品種間変異について, White と Quackenbush $^{9)}$ は2 251 品種について, 高木ら ${ }^{10)}$ は日本 と韓国の各地から収集した 172 品種の調査から, 脂肪酸 組成を支配する遺伝子の関与を示唆する広範な品種間変 異を見出している。また，ダイズの脂肪酸の遺伝につい ては, White と Quackenbush ${ }^{9)}$ が，含量を異にする品 種を交雑した場合に分離世代では連続した含量の分離が 観察されたことから，ダイズのリノール酸とリノレン酸 含量は微動遺伝子（poly gene）によって支配されてお り量的形質の遺伝を示すと報告している。他方，高木 $ら^{10)}$ は 172 品種の選抜から, 脂肪酸含量の大きな品種間 変異が認められた「松浦」と「オリヒメ」の交雑を行 い，オレイン酸とリノレン酸含量についてそれぞれ 2 個 と 1 個の遺伝子の支配があると報告している ${ }^{11)}$ 。しかし ながら，ダイズの自然集団について脂肪酸組成の遺伝変 異は大きいものの，環境による変動はさらに大きく，脂 肪酸組成を支配する遺伝子の一つ一つの効果は小さいと 考えている。

既存のダイズ遺伝資源の探索では，ナタネ，ヒマワ リ，ベニバナで見られるような脂肪酸組成を大きく変え る遺伝子 (major gene) は見出されなかった。従って, X 線などの放射線，EMS（ethyl methanesulfonate）な どの化学物質を使用した突然変異の誘発によって遺伝変 異を拡大して，ダイズの脂肪酸組成を変える新たな遺伝 子の探索が行われており，これらを利用した脂肪酸組成 
の改良に大きな期待が寄せられることになった。

\section{3 突然変異集団と自然集団における脂肪酸組成の比較}

われわれが 1987 年に開始した脂肪酸の突然変異体の 選抜実験では，ダイズの脂肪酸組成の遺伝変異を拡大す ることを目的として，ダイズ品種 BayにX 線を照射し て諸種の脂肪酸の突然変異体をスクリーニングすること を行った。その結果, 合計 12,266 個体の $\mathrm{M}_{2}$ 世代から, 46 系統の脂肪酸組成に関する突然変異体を得ることに 成功した。これら突然変異系統の一部を Table 2 に示す が，6.1\%の低パルミチン酸含量となる J3 ${ }^{12)}, 17.2 \%$ 高 パルミチン酸含量となる $\mathrm{J} 10^{12)} ， 21.2 \%$ 高ステアリン 酸含量となる $\mathrm{M} 25^{13)}, 48.6 \%$ 高オレイン酸含量となる $\mathrm{M} 23^{14)} ， 4.9 \%$ の低リノレン酸含量となる $\mathrm{M}-5^{15)}, 18.4 \%$
の高リノレン酸含量となる B739 ${ }^{16)}$ といった極めて多様 な突然変異体が得られた。また，詳細については次章に 述べるが，これら突然変異間の交雑から，脂肪酸含量の 変異をさらに大きくした系統が得られている。Table 3 は，われわれの研究によって得られた 46 系統の突然変 異体の脂肪酸組成と 99 品種のダイズ在来種の脂肪酸組 成の変異幅を比較したものである ${ }^{17)}$ 。その結果，突然変 異体では，Bayの一品種に起源するにもかかわらず，自 然集団から得られた 99 品種の脂肪酸組成の変異幅を越 えた大きな含量の変異が観察された。人為突然変異の誘 発では，ダイズの脂肪酸組成の遺伝的変異の拡大に極め て有効であり，交雑による遺伝子の集積によりさらに大 きな脂肪酸組成の変異の拡大が可能であることが明らか になった。

Table 2 Fatty Acid Composition (\% of total oil) of Different Mutant, and Their Genotypes.

\begin{tabular}{|c|c|c|c|c|c|c|}
\hline & \multicolumn{5}{|c|}{ Fatty acid } & \multirow[b]{2}{*}{ Genotype } \\
\hline & $\begin{array}{c}\text { Palmitic } \\
(16: 0)\end{array}$ & $\begin{array}{l}\text { Stearic } \\
(18: 0)\end{array}$ & $\begin{array}{c}\text { Oleic } \\
(18: 1)\end{array}$ & $\begin{array}{c}\text { Linoleic } \\
(18: 2)\end{array}$ & $\begin{array}{c}\text { Linolenic } \\
(18: 3)\end{array}$ & \\
\hline J 3 & 6.1 & 3.4 & 26.5 & 55.4 & 8.6 & sop 1 \\
\hline C1726 & 8.5 & 3.9 & 22.1 & 56.0 & 9.6 & fap 1 \\
\hline LPKKC-3 & 4.4 & 3.2 & 27.1 & 55.5 & 9.8 & sop 1, fap 1 \\
\hline KK 7 & 14.2 & 5.0 & 23.3 & 49.5 & 7.9 & fapx \\
\hline J 10 & 17.2 & 5.0 & 19.7 & 48.4 & 9.7 & fap2 \\
\hline HPKKJ10 & 21.6 & 5.7 & 18.0 & 45.6 & 9.0 & fap2, fapx \\
\hline $\mathrm{KK}-2$ & 10.3 & 7.2 & 23.1 & 51.6 & 7.9 & $s t_{1}$ \\
\hline M 25 & 9.5 & 21.2 & 15.6 & 44.0 & 9.8 & $s t_{2}$ \\
\hline M25KK2 & 9.4 & 31.4 & 12.4 & 38.4 & 8.4 & $s t_{1}, s t_{2}$ \\
\hline M11 & 10.3 & 4.3 & 35.8 & 41.4 & 8.2 & $o^{a}$ \\
\hline M 23 & 8.9 & 4.4 & 48.6 & 29.5 & 8.5 & ol \\
\hline$M-24$ & 10.0 & 5.3 & 27.3 & 51.5 & 5.9 & $\operatorname{fan} x^{a}$ \\
\hline$M-5$ & 9.8 & 4.9 & 25.5 & 55.3 & 4.9 & fan \\
\hline LOLL & 10.3 & 4.5 & 27.7 & 54.7 & 2.9 & fan, fanx $x^{a}$ \\
\hline Bay & 10.6 & 4.2 & 25.2 & 51.7 & 8.3 & \\
\hline
\end{tabular}

Table 3 Mean and Range of Fatty Acid Composition (\% of total oil) in Different Mutants and Natural Varieties of Soybean.

\begin{tabular}{lccccc}
\hline & \multicolumn{5}{c}{ Fatty acid } \\
\cline { 2 - 6 } & $\begin{array}{c}\text { Palmitic } \\
(16: 0)\end{array}$ & $\begin{array}{c}\text { Stearic } \\
(18: 0)\end{array}$ & $\begin{array}{c}\text { Oleic } \\
(18: 1)\end{array}$ & $\begin{array}{c}\text { Linoleic } \\
(18: 2)\end{array}$ & $\begin{array}{c}\text { Linolenic } \\
(18: 3)\end{array}$ \\
\hline Mutants & & & & 49.8 & 7.9 \\
Mean & 10.6 & 5.2 & 26.5 & $4.6 \sim 12.6$ \\
Range & $6.3 \sim 16.7$ & $2.9 \sim 16.1$ & $17.5 \sim 48.2$ & $32.2 \sim 60.5$ & 4.6 \\
\hline $\begin{array}{l}\text { Varieties } \\
\text { Mean }\end{array}$ & 12.1 & 2.9 & 25.1 & 51.9 & 8.0 \\
Range & $10.0 \sim 15.5$ & $1.6 \sim 4.1$ & $14.2 \sim 44.3$ & $36.6 \sim 61.1$ & $5.2 \sim 12.6$ \\
\hline
\end{tabular}




\section{4 ダイズの脂肪酸組成に関与する突然変異遺伝子の発見}

前述した様に X 線照射によって，われわれは，脂肪 酸組成が変化した数多くの突然変異体を得ることに成功 した。Table 2 には，これらの突然変異系統間で交雑を 行った結果，明らかになった遺伝子型を示している。こ こでは，他のグループのこれまでの研究成果も踏まえ て，低パルミチン酸，高パルミチン酸，高ステアリン 酸, 高オレイン酸, 低リノレン酸, 高リノレン酸の順に 脂肪酸含量に関与する突然変異遺伝子の遺伝様式につい て述べる。

\section{$4 \cdot 1$ 低パルミチン酸含量となる突然変異遺伝子}

通常のダイズ品種におけるパルミチン酸含量は 9 〜 12\%の範囲に分布していると考えられる。最初の低パル ミチン酸含量となる突然変異体 C1726 が Erickson らに より EMS 処理集団中より単離され, fap1 遺伝子 ${ }^{18)}$ が同 定された。その後, fapx 遺伝子 (A1937NMU173) ${ }^{19)}$, fap3 遺伝子 $(\mathrm{A} 22)^{20)}$, sop 1 遺伝子 $(\mathrm{J} 3)^{21)}$ 等も同じく 低パルミチン酸含量となる突然変異遺伝子として報告さ れた。これらの低パルミチン酸突然変異遺伝子のうち fap 1 遺伝子とfapx 遺伝子が 2 重劣性となった系統で は，パルミチン酸含量が $4.4 \%$ となり ${ }^{19)}$, fap1 遺伝子と fap 3 遺伝子が 2 重劣性となった系統では $3.5 \%$ 22) まで低 下することが報告された。われわれの研究室においても $\mathrm{X}$ 線照射集団から複数の低パルミチン酸突然变異体を単 離しているが，このうち J3 と J.R. Wilcox から分讓を受 けた C1726 との交雑後代から, sop 1 遺伝子と fap 1 遺伝 子が 2 重劣性となりパルミチン酸含量が $4.4 \%$ の LPKKC-3 が得られている ${ }^{21)}$ (Table 2)。

\section{$4 \cdot 2$ 高パルミチン酸含量となる突然変異遺伝子}

Erickson ら ${ }^{18)}$ は，17.3\%の高パルミチン酸含量となる C1727 突然変異体を単離し，この形質を支配する fap 2 遺伝子について報告している。また, Rahman ら ${ }^{23)}$ は, われわれの研究で得られた高パルミチン酸突然変異体の うち KK7 と $\mathrm{J} 10$ の交雑から, fapx 遺伝子と fap 2 遺伝子 が 2 重劣性となった HPKKJ10 系統を作出し, このパル ミチン酸含量が $21.6 \%$ と両親を越えた高含量となるこ と, ならびに, J10の高パルミチン酸含量は C1727 と同 じ fap2 遺伝子によって支配を受けていることを報告し ている。高パルミチン酸含量とする遺伝子については, この他にも fap4 遺伝子 $(\mathrm{A} 24)^{24)}$, fap5 遺伝子 ${ }^{25)}$, fap6 遺伝子 ${ }^{26)}, f a p 7$ 遺伝子 ${ }^{27)}$ が報告されており,このうち $f a p 2-b$ 遺伝子, fap4 遺伝子および fap 6 遺伝子を 3 重劣 性とした場合には，39.8\%という更に高いパルミチン酸 含量となることも明らかになっている ${ }^{26)}$ 。

\section{$4 \cdot 3$ 高ステアリン酸含量となる突然変異遺伝子}

一般的なダイズ品種のステアリン酸含量は総じて低 く, 2 5\%程度の範囲に分布している。Graef ら ${ }^{28)}$ は, EMS もしくはアジ化ナトリウム処理を行った集団から 3 系統の高ステアリン酸含量となる突然変異体を得てい る。これら突然変異体のうちで最も効果が高かった A6 系統では，30.4\%にまでステアリン酸含量の上昇が認め られたが，これら全ての系統に生じた突然変異は同一の $f a s^{\mathrm{a}}$ 遺伝子座に由来するものであったと報告している。 また，Bubeck ら ${ }^{29)}$ は，新たに単離したST1, ST2, ST3, ST4の 4 系統の高ステアリン酸突然変異体と前述の A6 を交雑したところ，ST2 とA6 の組み合わせでのみ両親 を越える高ステアリン酸含量の子孫の分離が観察された ことから，ST2の高ステアリン酸は $f a s^{\mathrm{a}}$ 遺伝子とは異 なる他の遺伝子座に生じた突然変異であると結論づけて いる。われわれも X 線照射による突然变異の誘発から， 高ステアリン酸含量となる諸種の突然変異体を得てい る。このうち KK-2 と M25 の交雑によって得られた $s t_{1}$ 遺伝子と $s t_{2}$ 遺伝子の 2 重劣性系統は, $31.0 \%$ 以上とい う極めて高いステアリン酸含量を示すことが明らかに なった ${ }^{30)}$ (Table 2)。

\section{$4 \cdot 4$ 高オレイン酸含量となる突然変異遺伝子}

近年の健康志向から注目を集めているオレイン酸含量 の品種間変異は, 17.5\%〜 48.2\%の範囲であり（Table 3), 他の脂肪酸と比較するとその変異の幅が比較的大き い。しかしながら，オレイン酸含量は環境（特に種子登 熟期の気温）による変動が極めて大きく，不安定な形質 であると考えられており，㚙然変異体についての報告も ほとんどなされていなかった。われわれの研究グループ では，世界に先駆けて，50.2\%の高オレイン酸含量とな る突然変異体 M23のX 線照射集団からの単離とその遺 伝様式について報告を行っている ${ }^{14,31)}$ 。また，異なる変 異集団から得られた高オレイン酸突然変異体 M11 と M23 の交雑からは，M11の低オレイン酸含量が部分優 勢となり， $\mathrm{F}_{2}$ 世代では両親を越える高オレイン酸含量 の分離は見られなかったことから，M11の高オレイン酸 突然变異は M23 の ol 遺伝子と同一座に生じたものであ ると考え $o l^{a}$ 遺伝子と名付けた ${ }^{32)}$ (Table 2)。

\section{$4 \cdot 5$ 低リノレン酸含量となる突然変異遺伝子}

リノレン酸は，ダイズ油脂の自動酸化による品質劣化 の最大の原因であると考えられており，1\%以下に低下 させることが理想であると考えられている。しかしなが ら，ダイズの主要品種におけるリノレン酸の含量は $6 \%$ から $9 \%$ の間に分布していることから, Hammond と Fehr ${ }^{33)}$ は，EMS 処理によって変異を誘発した集団から $3.4 \%$ の低リノレン酸含量となる A 5 を単離し fan 遺伝子 
を同定している。また，Fehr ら ${ }^{34)}$ は，新たに得られた 低リノレン酸突然変異体 $\mathrm{A} 23$ と $\mathrm{A} 5^{35)}$ の交雑によって, fan 遺伝子とfan 2 遺伝子が 2 重劣性となる A 16 系統と A17 系統を作出し，これらの系統のリノレン酸含量が両 親の含量を越えて低下したと報告している。われわれの グループにおいても, 複数の低リノレン酸含量となる突 然変異体の単離に成功しているが，このうち $\mathrm{M}-24$ と M-5 の交雑から得られた LOLL はfan 遺伝子と fanx $x^{\mathrm{a}}$ 遺 伝子が 2 重劣性となった系統であり，2.9\%までリノレン 酸含量が低下している ${ }^{36)}$ (Table 2)。

\section{$4 \cdot 6$ 高リノレン酸含量となる突然変異遺伝子}

われわれは，先に述べた低リノレン酸となる変異とは 逆にリノレン酸含量が増加する突然変異体も単離してい る。この B739 では, リノレン酸含量が 18.4\%まで増加 しており ${ }^{16)}, \quad l i n^{\mathrm{h}}$ 遺伝子が原因となっていることを報告 した ${ }^{37)}$ 。

\section{5 ダイズの脂肪酸生合成経路と遺伝子重複}

Fig. 1 には，ダイズ種子中に蓄積される主要な脂肪酸 の生合成経路を示している。パルミチン酸（16:0）は, 脂肪酸合成の出発物質であるマロニル-ACP (4:0) が 縮合を繰り返し，パルミトイル-ACPとして合成された 後, チオエステラーゼによって脂肪酸部分の切り出しが おこなわれる。パルミトイル-ACP は, Gm $B K A S I I を$ 含む鎖長延長酵素の働きによりステアロイル $-\mathrm{ACP}$ へと 変換され，同様にステアリン酸（18：0）が生成される。 続いてステアロイル-ACP 不飽和化酵素 (GmSte) の働 きによってオレオイル-ACP に変換された後, チオエス テラーゼの働きによってオレイン酸 $(18: 1)$ が切り出 され，小胞体型 $\omega-6$ 脂肪酸不飽和化酵素 (GmFAD2) および小胞体型 $\omega-3$ 脂肪酸不飽和化酵素 $(G m F A D 3)$ によってリノール酸 (18：2）およびリノレン酸（18：

3）の順で生合成されることが明らかになっている。

前章で述べたように，ダイズの脂肪酸組成に関する突 然変異体を用いた遺伝学的解析から, 各脂肪酸生合成の ステップに複数個の遺伝子が係わっていることが示唆さ れた。そこでわれわれは，これら一連の脂肪酸生合成反 応に関与する酵素のうち GmBKASII, GmSte, GmFAD2, $G m F A D 3$ をコードする遺伝子の単離を試み, それぞれ
の酵素について複数の独立した遺伝子を得ることに成功 した。また，突然変異系統から抽出したゲノミック DNAに対して，これらの遺伝子をプローブとしたサザ ンブロット分析を行なったところ，一部の突然変異体に おいて特定の酵素遺伝子に欠失が観察され，脂肪酸含量 の遺伝との間に完全な一致が認められた ${ }^{38,39,40)}$ 。更に詳 細な分析の結果，サザンブロット分析では遺伝子の欠失 が検出できなかった突然変異体の一部でも，異なる酵素 遺伝子の ORF 上に一塩基から数十塩基程度の小さな欠 失が生じ，酵素活性が消失しているものが存在すること も明らかになっている。

4 倍体由来のゲノムを持つダイズでは広範讲の遺伝子 重複が生じていることが明らかになっていることから， 脂肪酸生合成に関与する酵素群にも複数のアイソザイム が存在していると予想される。そこで，これらの突線変 異体においてどのアイソザイム遺伝子に変異が生じたの かを分子レベルで理解することは，今後，ダイズの脂肪 酸含量についての育種を進めて行く上で非常に重要な情 報となると考えられる。

ここではその一例として，リノール酸からリノレン酸 への不飽和化のステップに関するわれわれの研究成果 ${ }^{41)}$ について紹介する。われわれは，突然変異誘発の際の原 品種として使用してきたBay より４種類の小胞体型 $\omega-3$ 脂肪酸不飽和化酵素遺伝子（GmFAD 3-1a， GmFAD3-1b, GmFAD3-2a, GmFAD3-2b) を単離し, これまでに得られている低リノレン酸含量となる突然変 異体におけるこれらの遺伝子の変異を解析した。その結 果，M-24 では GmFAD3-1a 遺伝子の ORF 上に 1 塩基 の欠失が生じており，フレームシフト変異を生じている ことが明らかになった。また，M-5でも同様に GmFAD3-1b 遺伝子において ORF 上の 19 塩基が久失 しフレームシフト変異を生じていた他, J18, KM1495, IL8 では GmFAD3-1b 遺伝子全体にわたる欠失が生じ ていることが明らかになった（Table 4)。ダイズの小胞 体型 $\omega-3$ 脂肪酸不飽和化酵素遺伝子を導入した出芽酵母 (Saccharomyces cerevisiae) を用いて，これらの変異が 酵素活性に与える影響を評価したところ，M-24および $\mathrm{M}-5$ で見出された変異によって，B a y 由来の $G m F A D 3-1 a$ および $G m F A D 3-1 b$ 遺伝子産物では検出

Table 4 Genotypes of Different Fatty Acid for Mutant Gene and Their Changes of the Coding Region.

\begin{tabular}{lcccc}
\hline Mutant line & Character & Genotype & Enzyme gene & Mutation type of coding region \\
\hline M-24 & Low Linolenic & fanx & GmFAD3-1a & Single-base pair deletion on ORF \\
M-5 & Low Linolenic & fan & GmFAD3-1b & 19-base pair deletion on ORF \\
J18 & Low Linolenic & fan & GmFAD3-1b & Large deletion containing ORF region \\
\hline
\end{tabular}


された酵素活性が完全に消失していることも明らかと なった。更に，酵母における実験結果と RT-PCR を用 いた遺伝子発現パターンの解析結果を合わせて判断する と, GmFAD3-2 $a$ 遺伝子が更なる低リノレン酸含量の 実現のための重要なターゲットとなることが示唆され た。

\section{6 新しい脂肪酸組成を持つダイズの作出を目指して}

前章までに，われわれが行った突然変異遺伝子につい ての研究成果を含めダイズの脂肪酸組成の改良に利用可 能な遺伝資源について述べてきた。

$\mathrm{X}$ 線の照射等によって得られた諸種の脂肪酸含量に関 する突然変異体のうち, 異なる遺伝子 (座) に突然変異 を生じたもの同士であれば，交雑により組み合わせて改 良に使用することが可能である。すなわち，異なる脂肪 酸含量に対する突然変異遺伝子を組み合わせることによ り，複数の脂肪酸含量を同時に変化させることや，同じ 脂肪酸含量に対して相加的に働く突然变異遺伝子（同義 遺伝子）の組み合わせにより, 特定の脂肪酸含量の変化 を更に大きくすることも可能となる。

そこで本章では，これらの遺伝資源を利用したダイズ の脂肪酸含量の改良の現状について, 特に市場価值の高 い高オレイン酸含量で低リノレン酸含量のダイズを中心 に説明を行う。

多価不飽和脂肪酸（リノール酸とリノレン酸）は，ダ イズ油脂の自動酸化による品質劣化および過酸化物発生 の原因物質であることから，オレイン酸含量を高め, リ ノレン酸含量を低下させた品種の育成がダイズ油脂の市 場価格向上のための最大のターゲットとなっている。
そこでわれわれは，高オレイン酸含量となる突然変異 体 M23 系統と低リノレン酸含量となる LOLL 系統（後 述する）の組合せから高オレイン酸で低リノレン酸含量 となる DHL 系統を開発した ${ }^{42)}$ 。この DHL 系統は, 原品 種 $\mathrm{Bay}$ の脂肪酸組を大きく超えた高オレイン酸で (50.6\%) かつ低リノレン酸含量（2.7\%）の油脂を生産 する。また，DHL 系統とほぼ同程度の高オレイン酸で 低リノレン酸含量となる N98-4445A 系統が，USDAARS によって育成され，普及に移されている。この系 統のオレイン酸含量は $58.9 \%$ ，リノレン酸含量は $2.6 \%$ であり (Table 5)，オレイン酸含量には 5〜6個の遺伝 子が関与していると推定されている。さらに最近になっ て, Alt ら ${ }^{43)}$ は, 高オレイン酸含量の FA22 系統, N984445A 系統, M23 系統の相互交雑を行い, その後代の オレイン酸含量を調査したところ，N98-4445A 系統と M23 系統の組み合わせで，両親を越える $73 \%$ オレイ ン酸含量となる（N98-4445A × M23）-1 系統が得られ たことを報告している（Table 5)。この高オレイン酸含 量の系統は, M23 の $o l$ 遺伝子に N98-4445A の高オレイ ン酸含量となる複数の遺伝子が加わって, 超越分離 (transgressive segregation) を示したものであろうと考 えられた。

この他にも高オレイン酸含量となるダイズとして, 遺 伝子組換え技術によって作成された High Oleic Soybean (Table 5) が知られている。これは $G m F A D 2-1$ 遺伝子 をコサプレッションにより阻害したものであり，85\%以 上の高いオレイン酸含量となる。また，この系統のオレ イン酸含量の変動幅は $83 \%$ から $86 \%$ までであり, 非常 に安定していることも明らかになっている。これに対し

Table 5 Gene Combinations that Alter the Fatty Acid Composition and Some Transcendent Lines with High Oleate and Low Linolenate.

\begin{tabular}{|c|c|c|c|c|c|c|c|c|c|}
\hline \multirow{3}{*}{ Line } & \multicolumn{5}{|c|}{ Fatty acid } & \multirow{2}{*}{\multicolumn{4}{|c|}{ Genotype \& Reference }} \\
\hline & \multirow{2}{*}{$\begin{array}{c}\text { Palmitic } \\
(16: 0)\end{array}$} & \multirow{2}{*}{$\begin{array}{l}\text { Stearic } \\
(18: 0)\end{array}$} & \multirow{2}{*}{$\begin{array}{l}\text { Oleic } \\
(18: 1)\end{array}$} & \multirow{2}{*}{$\begin{array}{l}\text { Linoleic } \\
(18: 2)\end{array}$} & \multirow{2}{*}{$\begin{array}{c}\text { Linolenic } \\
(18: 3)\end{array}$} & & & & \\
\hline & & & & & & Palmitic & Searic & Oleic & Linolenic \\
\hline HPS & 23.1 & 11.4 & 13.3 & 44.6 & 8.6 & sop2,fap2 & $S t_{1}, s t_{2}$ & $\mathrm{OI}$ & Fan,Fanx \\
\hline MHPDHL & 19.3 & 2.2 & 31.8 & 43.4 & 3.3 & Sop2,fap2 & $S t_{1}, S t_{2}$ & ol & $f a n, f a n x^{a}$ \\
\hline HPLOLL & 25.2 & 2.8 & 18.5 & 50.9 & 2.6 & sop2,fap2 & $S t_{1}, S t_{2}$ & $\mathrm{Ol}$ & fan, fan $x^{a}$ \\
\hline HSO & 11.2 & 11.8 & 20.4 & 48.2 & 8.4 & Sop 1,Fap2 & $S t_{1}, s t_{2}$ & ol & Fan,Fanx \\
\hline $\mathrm{DHL}$ & 11.7 & 2.8 & 50.6 & 32.2 & 2.7 & Sop1,Fap2 & $S t_{1}, S t_{2}$ & ol & fan, $\operatorname{fan} x^{a}$ \\
\hline N98-4445A & 9.6 & 4.0 & 58.9 & 25.0 & 2.6 & USDA-ARS/I & vorth Carc & olina St & tate Univ. \\
\hline$(N 98-4445 A \times M 23)-1$ & 8.5 & 3.6 & 73.0 & 11.6 & 3.3 & J.L. Alt et al & ., 2005 & & \\
\hline High Oleic Soybean & 6.4 & 3.3 & 85.6 & 1.6 & 2.2 & GmFad2-1 & ene Trans & sforma & Ition Line \\
\hline $1 \%$-Linolenate & 10.3 & 5.0 & 30.0 & 53.4 & 1.3 & A.J. Rosset & 1., 2000. & & $1, \operatorname{fan} 2, \operatorname{fan} 3$ \\
\hline Bay & 11.8 & 2.4 & 25.2 & 53.0 & 7.6 & Sop1, Fap2 & $S t_{1}, S t_{2}$ & $\mathrm{OI}$ & Fan, Fanx \\
\hline
\end{tabular}


て，われわれが単離した突然変異体 M23 系統において も，この High Oleic Soybeanの標的と同じ GmFAD2-1 遺伝子に欠失が生じていることが明らかになっている が39)，そのオレイン酸含量の分布は $42 \%$ か $58 \%$ まで と大きな変動幅があった。これはHigh Oleic Soybean では, GmFAD2-1 遺伝子の導入が引き金となって, 塩 基配列の相同性が高い他の $\omega-6$ 不飽和酵素遺伝子（アイ ソザイム遺伝子）についても発現の抑制（gene silencing）が引きおこされた結果であろうと考えられる。

一方，われわれは，低リノレン酸含量となる突然変異 体 M-5 系統と M-24 系統の交雑から前述の LOLL 系統 を作成した。この系統では $2.8 \%$ こまでリノレン酸含量 の低下が浔められたが，さらに低リノレン酸含量を低下 させる第 3 の遺伝子の探索を続けてきた。この間に， M-5 系統に対してX 線を再照射した集団から，さらに 低リノレン酸含量となる MS382 の選抜を報告している が ${ }^{44)}$, 新たな遺伝子座に生じた突然変異については未だ 発見できていない。

これに対して Fehr と Hammond (Iowa State University）は，低リノレン酸含量となるfan3 遺伝子 ${ }^{45)}$ を見 出し, $f a n 1, f a n 2, f a n 3$ の三重劣性となりリノレン酸含 量が $1.3 \%$ まで低下した低リノレン酸系統（1\% - Linolenate 系統）の作出に成功したと報告している ${ }^{46)}$ 。また最 近では，同じグループによって，この $1 \%$-Linolenate 系 統と前述した高オレイン酸系統の交雑により，高オレイ ン酸でかつ低リノレン酸含量となるダイズ品種の育種が 進められている。

またわれわれのグループでは，これ以外の脂肪酸につ いても数種の突然変異体を組み合わせることにより，こ れまでにない脂肪酸組成を持ったダイズの作出を試みて きた ${ }^{42,47)}$ (Table 5)。例えば，HPS 系統および HSO 系統 は 3 個, HPLOLL 系統は 4 個, MPDHL 系統は 5 個の 異なる突然変異遺伝子を組み合わせることにより，原品 種 Bay とくらべて著しく異なる脂肪酸組成を実現した ものである。

\section{7 おわりに}

現在，われわれは，前述した DHL 系統のアメリカで の試験栽培を開始する一方，国産ダイズの付加価值を向 上させる目的で，佐賀県農業試験研究センターと共同し て，高オレイン酸でかつ低リノレン酸含量となり，健康 に対する効果が期待できる新品種の育成を進めている。

脂肪酸組成の改良のように，多数の突然変異遺伝子を 組み合わせた複雑な育種を効率的に進めて行くために は，目的とする遺伝子を識別するための分子マーカーの 利用が重要となる。とくに，ゲノム中での相同遺伝子の
重複度が高い植物種を対象とする場合や，環境による変 動が大きな形質についての改良を行う場合は，分子マー カーの必要性がさらに高まるものと考えられる。このよ うな観点から，われわれは，突然变異体の探索に始ま り, その変異遺伝子の DNA レベルでの解析を行い, 分 子マーカーの開発を進めてきた。

今後，これら一連の研究から得られた知見を基にして 開発された新たなダイズ品種が，広く普及し，植物油脂 市場への大きな波及効果を生んでくれることを切に願い つつ，本稿の締めくくりとしたい。

\section{文献}

1) S.M. Grundy, New Engl. J. Med., 314, 745-8 (1986).

2) H. Liu \& P.J. White, J. Am. Oil Chem. Soc., 69, 828-32 (1992).

3) T.J. Mounts, K. Warner, G.R. Rist, R. Kleiman, W.R. Fehr, E.G. Hammond \& J.R. Wilcox, J. Am. Oil Chem. Soc., 65, 624-8 (1994).

4) H.J. Dutton, C.R. Lancaster, C.D. Evans \& C.I. Cowan, J. Am. Oil Chem. Soc., 28, 115-8 (1951).

5) C.D. Evans, H.A. Monser, D.G. McConnell, J.C. Cowan, J.L. Cartter \& F.I. Collins, J. Am. Oil Chem. Soc., 49, 578 (1972).

6) United States Food and Drug Administration, A food labeling guide, U.S. Dept. of Health and Human Serv. Publ. Washington, D.C. (1999).

7) B.L. Harvey \& R.K. Downey, Can. J. Plant Sci., 44, 104-11 (1964).

8) P.F. Knowles, J. Am. Oil Chem. Soc., 46, 130-2 (1969).

9) H. B. Jr. White \& F. W. Quackenbush, J. Am. Oil Chem. Soc., 38, 113-7 (1961).

10）高木㭌，松尾巧，池田邦寞，佐賀大農彙，47，53-64 (1979).

11）高木㭌, 松尾巧, 岸川英利, 育種学雑誌, 36, 163-76 (1986).

12) Y. Takagi, S.M. Rahman, H. Joo \& T. Kawakita, Biosci. Biotech. Biochem., 59, 1778-9 (1995).

13) S.M. Rahman, Y. Takagi, K. Miyamoto \& T. Kawakita, Biosci. Biotech. Biochem., 59, 922-3 (1995).

14) S.M. Rahman, Y. Takagi, K. Kubota, K. Miyamoto \& T. Kawakita, Biosci. Biotech. Biochem., 58, 1070-2 (1994).

15) Y. Takagi, A.B.M.M. Hossain, T. Yanagita, T. Matsueda \& A. Murayama, Agric. Biol. Chem., 54, 1735-8 (1990).

16) Y. Takagi, A.B.M.M. Hossain, T. Yanagita \& S. Kusaba, Japan. J. Breed., 39, 403-9 (1989).

17) Y. Takagi \& S.M. Rahman, Bull. Fac. Agr. Saga Univ., 79, 23-7 (1995).

18) E.A. Erickson, J.R. Wilcox \& J.F. Cavins, J. Hered., 79, 465-8 (1988).

19) W.R. Fehr, G.A. Welke, E.G. Hammond, D.N. Duvick \& S.R. Cianzio, Crop Sci., 31, 88-9 (1991).

20) S.R. Schnebly, W.R. Fehr, G.A. Welke, E.G. Hammond, \& D.N. Duvick, Crop Sci., 34, 829-33 (1994)

21) T. Kinoshita, S.M. Rahman, T. Anai \& Y. Takagi, Breed- 
ing Sci., 48, 377-81 (1998).

22) T.F. Horejsi, W.R. Fehr, G.A. Welke, D.N. Duvick, E.G. Hammond \& S.R. Cianzio, Crop Sci., 34, 331-4 (1994).

23) S.M. Rahman, T. Kinoshita, T. Anai \& Y. Takagi , J. Heredity, 90, 423-8 (1999).

24) S.R. Schnebly, W.R. Fehr, G.A. Welke, E.G. Hammond \& D.N. Duvick, Crop Sci., 34, 829-33 (1994)

25) D.L. Stoltzfus, W.R. Fehr, G.A. Welke, E.G. Hammond \& S.R. Cianzio, Crop Sci., 40, 647-50 (2000).

26) J.M. Narvel, W.R. Fehr, J. Ininda, G.A. Welke, E.G. Hammond, D.N. Duvick \& S.R. Cianzio, Crop Sci., 40, 635-9 (2000).

27) D.L. Stoltzfus, W.R. Fehr, G.A. Welke, E.G. Hammond \& S.R. Cianzio, Crop Sci., 40, 1538-42 (2000).

28) G.L. Graef, W.R. Fehr \& E.G. Hammond, Corp Sci., 25, 1076-9 (1985).

29) D.M. Bubeck, W.R. Fehr \& E.G. Hammond, Corp Sci., 29, 652-6 (1989).

30) S.M. Rahman, Y. Takagi \& T. Kinoshita, Theor. Appl. Genet., 95, 772-6 (1997).

31) Y. Takagi \& S.M. Rahman, Theor. Appl. Genet., 92, 179-82 (1996).

32) S.M. Rahman, Y. Takagi \& T. Kinoshita, Crop Sci., 36, 1125-8 (1996).

33) E.G. Hammond \& W.R. Fehr, Crop Sci., 23, 192 (1983).

34) W.R. Fehr, G.A. Welke, E.G. Hammond, D.N. Duvick \& S.R. Cianzo, Crop Sci., 32, 903-6 (1992).

35) D.M. Bubeck, W.R. Fehr \& E.G. Hammond, Crop Sci.,
29, 652-6 (1989).

36) S. M. Rahman, T. Kinoshita, T. Anai, S. Arima \& Y. Takagi, Crop Sci., 38, 702-6 (1998).

37) S.M. Rahman, Y. Takagi \& S. Towata, Breeding Sci., 44, 267-70 (1994).

38) Y. Yamasita, T. Kinoshita, S.M. Rahman, K. Okada, T. Anai \& Y. Takagi, Bull. Fac. Agr., Saag Univ., 83, 31-6 (1998).

39) T. Kinoshita, S.M. Rahman, T. Anai \& Y. Takagi, Bull. Fac. Agr., Saag Univ., 83, 37-42 (1998).

40) S.M. Rahman, T. Kinoshita, T. Anai \& Y. Takagi, Bull. Fac. Agr., Saga Univ., 83, 43-8 (1998).

41) T. Anai, T. Yamada, T. Kinoshita, S.M. Rahman \& Y. Takagi, Plant Sci., 168, 1615-23 (2005).

42) S.M. Rahman, T. Kinoshita, T. Anai \& Y. Takagi, Crop Sci., 41, 26-9 (2001).

43) J.L. Alt, W.R. Fehr, G.A. Welke \& J.G. Shannon, Crop Sci., 45, 2005-7 (2005).

44) Y.Takagi, S.M. Rahman, T. Anai, S.K. Wasala, T. Kinoshita \& M. Khalekuzzaman, Breeding Sci., 49, 1-5 (1999).

45) W.R. Fehr \& E.G. Hammond, U.S. Patent 55344325. Date issued: 9 Dec. (1998).

46) A.J. Ross, W.R. Fehr, G.A. Welke \& S.R. Cianzio, Crop Sci., 40, 383-6 (2000).

47) S.M. Rahman, T. Anai, T. Kinoshita, S. Arima \& Y. Takagi, Breeding Sci., 54, 225-9 (2004). 